\title{
'TWO REVOLUTIONS BEHIND: \\ IS THE ETHIOPIAN ORTHODOX CHURCH AN OBSTACLE OR CATALYST FOR SOCIAL DEVELOPMENT?'1
}

\author{
JA Loubser \\ University of Zululand
}

\begin{abstract}
As part of a project to investigate the spiritual and moral roots for an African Renaissance the paper employs an inter-disciplinary approach, investigating the intersection between religion and social development. This is done with reference to developmental issues as they become manifest in Ethiopia. An analysis of the social role of the Ethiopian Orthodox Church is accompanied by a critical review of some theories and strategies for social development. Since Ethiopia is one of the major beneficiaries of US and international aid the paper also considers options for sustainable social development.
\end{abstract}

\section{Introduction}

This paper is the direct result of a confrontation with the poverty and desperation experienced during a field trip to Ethiopia. ${ }^{2}$ While investigating the Ethiopian Orthodox tradition as part of a university project on the moral and spiritual roots for an African Renaissance, we did not expect such wide-scale poverty and human need in a country that is noteworthy for its contribution to global culture.

Of the $80 \%$ population of the planet marginalized by the global economy, the people of Ethiopia count among those who are the worst off. ${ }^{3}$ The plight of its circa 60 million people with more than 80 different ethnic groups is highlighted by the following:

- 440000 new cases of HIV infection (with the virulent heterosexual C-strain) were estimated for $1999 ;^{4}$

- vast sections of the predominantly rural population are without access to basic medical care;

- seasonal famine regularly affects large sections of the population (4 million Ethiopians are dependent on foreign aid for food) ${ }^{5}$

- half of the children under five are estimated to be malnourished. ${ }^{6}$ outside the major towns and cities the transport infrastructure is in serious disrepair.

1. Paper read at the Religion and Social Sciences Section, AAR Annual Meeting Nashville November 21, 2000.

2. The trip was undertaken from 26 October to 10 November 1999, together with Prof. A.L.M. Pitchers of the University of Zululand.

3. Ethiopia, with an average per capita income of $\$ 100$ annually is considered to be the second or third poorest country in the world.

4. According to Prof. Walter Prozesky, leader of the South African Aids Research Team, at a conference of "Die Suid Afrikaanse Akademie vir Wetenskap en Kuns", University of Bloemfontein, June 2000.

5. Cf. Encyclopaedia Britannica Year Book 1998. Abegaz (1994:301) notes that between 1960 and 1990 the food availability per head declined by one-third.

6. Hodd, 1998:731. 
If living conditions are harsh for Africans, it is even more so for the average Ethiopian. How this is experienced at the grassroots of society can be gauged from the popular rhymes through which the peasants express their feelings. Fekade Azeze recorded some of these during the famine of 1984/85 in the Northern Shäwa region. The three selected rhymes speak of humiliation, hunger and cynicism.

On this cruel day, it used me so cruelly

It reduced me to a cowherd,

It gave my sister to the vultures. ${ }^{7}$

Of the year Seventy Seven

There are many stories to tell!

Many a man has drunk,

Mixing soil with water.

(Just to calm his hunger). ${ }^{8}$

Famine (in the year' 77 of the Julian calendar as is used in Ethiopia) is seen as an act of God. It is the price of sin, but not all victims accept it as such. ${ }^{9}$

"Thank you God!" says the poor, "Oh thank You!"

While swimming in abject poverty,

And knowing quite well,

[That] his granary is empty! $!^{10}$

Though a variety of reasons for drought and famine are explored in peasant thinking, it is clear from Azeze's collection that scientific explanations are not part of the popular wisdom, nor do they reflect any strategic planning for avoiding such disasters in future. ${ }^{11}$ While this is to be expected among peasants, it is a reflection of the average level of education of the population.

Under the Derg (the Communist Rule 1974-1991) a massive redistribution of land was brought about, resulting in what has been called the most equitable system of land ownership in the world (with all land belonging to the state). With the "implosion" of the economy under the Derg, the agricultural programs also collapsed, leaving people even more dependent on traditional subsistence farming than before. ${ }^{12}$ From a review of the Ethiopian economy in the years $1991-1992^{13}$ it becomes clear that it is still heavily dependent on agriculture.

It is somewhat strange that Ethiopia finds itself in this position, for it had a number of factors working in its favour. Unlike most African countries, it suffered only a brief spell of colonial rule (Italian occupation from 1936-1941). It is also the only Sub-Saharan country that has developed a writing system and calendar. It has a literary culture, dating back more than 2000 years. Its Christian tradition reaches back to the fourth century. At various occasions the country was at the forefront of international initiatives (United Nations,

7. Azeze, 1998:60.

8. Azeze, 1998:63

9. Azeze, 1998:112.

10. Azeze, 1998:97.

11. The pre-scientific view of nature predominant among the EOC membership, is described by Berhane-Selassie (in Hallman 1994:155-172).

12. Agriculture accounts for $40 \%$ of the country's output and employs $75 \%$ of the labour force (Abegaz 1994:9).

13. Abegaz, 1994:8ff. 
Organisation of African Unity). It has also been a major recipient of international aid over the past century. ${ }^{14}$

One would have expected that this country with its adequate natural resources ${ }^{15}$ and the cultural potential of its people would have had a better chance to feed its population and care for its sick. One also would have expected the country to be a prime travel destination - somewhat like Mexico - for its ancient culture and breathtaking nature. Instead we experienced widespread xenophobia and a persistent anger at "colonialism". ${ }^{6}$

\section{The economy}

A brief profile of the Ethiopian economy shows that a decade after moving away from a "hyper-centralized and militarised state socialism", ${ }^{17}$ progressive measures such as democratisation, the liberalization of trade, and the privatisation of state properties are beginning to pay off. ${ }^{18}$ However, this alters nothing to the fact that the average Ethiopian has seen his or her living standard declining during the last three decades. ${ }^{19}$ A World Bank projection foresees economic stagnation for some time to come in the whole of SubSaharan Africa (SSA). ${ }^{20}$

\section{Analysis of causes for underdevelopment}

According to the International Monetary Fund the malaise of SSA is not related to globalisation but it is the result of internal problems, such as natural disasters and especially the mismanagement of the economies. The World Bank is of the same opinion:

“Governments made a dash for 'modernization,' copying, but not adapting, Western models. The result was poorly designed public investments in industry; too little attention to peasant agriculture; too much intervention in areas in which the state lacked managerial, technical, and entrepreneurial skills; and too little effort to foster grassroots development". ${ }^{21}$

In the case of Ethiopia it is fairly easy to point out some causes for the present state of the economy.

Political mismanagement and corruption before and during the "Derg", the war with Somalia (1977), the civil war (1988-1991) and the recent war with Eritrea (1998-2000).

The lack of sophisticated skills to deal with the basic needs of the population - a rough estimate is that 200000 middle class, educated people perished during the Derg, while as many went into exile.

Devastating droughts in 1984/85, 1993/4 and 1997/8, as well as seasonal hunger contribute to the fact that $60 \%$ of the population live under the absolute poverty line. ${ }^{22}$

14. A review of the projects listed for Ethiopia on the IMF website gives an impression of this.

15. For brief summaries of natural resources, see Hodd (1998:731) and Balletto (1975: 307-308).

16. Various interviewees expressed such sentiments. On a question about what was needed for the country to recover its economy, a senior official in Bahir Dar responded, "Just leave us alone."

17. Abegaz, 1994:17.

18. For a brief summary of the country's New Economic Policy, see Balletto, 1995:307. For the year 1992/3 an annual growth of $7.6 \%$ was achieved thanks to the inflow of foreign aid and the adoption of recovery measures.

19. Abegaz, 1994:5.

20. Abegaz, 1994:6.

21. The World Bank, 1989, cited by Abegaz, 1994:3.

22. Abegaz, 1994:9. 
Low commodity prices for coffee, hides and skins on international markets, which since 1984 have lost $25 \%$ of their value.

\section{Remedies for the economy}

Abegaz remarks that economic restructuring in SSA does not happen overnight, and that a decade is even too short a span to expect drastic results. In assessing strategies for the recovery of the economy, there are basically two options to consider. Each of these exhibit some shortcomings, which will be discussed, leading up to a thesis of this paper, viz., that social and cultural impact studies are of vital importance for the long-term economic development.

\section{The 'neoclassical model'}

This is mainly the model of the International Monetary Fund and the World Bank. The projects of the IMF are mainly aimed at short-term fiscal and monetary stabilization in crisis situations. Obviously, this can only serve as a temporary remedy for the symptoms of a problem that goes much deeper. This is illustrated by the fact that such projects have been implemented during the last four decades in Ethiopia. ${ }^{23}$

The WB takes a medium-term view and aims at systemic adjustment. The WB (1989) argues that SSA's problems are mainly internal and cites South East Asia in comparison. "The gist of the problem is taken to lie squarely in a misconceived development strategy peddled by inept or parasitic African governments". ${ }^{24}$

The philosophy of both these bodies are neo-classical in the sense that they promote liberalization of the economy with the understanding that private ownership and open markets are what create growth. Often their policies involve shock therapy causing severe disruption of the population. Long-term economic growth and cultural transformation are not in the focus of programs of either body.

\section{The 'structural model'}

This is the model of the UN Economic Commission for Africa (ECA) and also of UNICEF. This approach rests on a more comprehensive and longer-term view of the structural features of African economies, e.g., the widespread phenomenon of subsistence farming, the large proportional role of the informal sector, the degraded environment, weak institutional capabilities and excessive dependence on external trade. ${ }^{25}$ There is an emphasis to meet human needs.

In a summary of a book on Globalization and the United Nations, by Victor Menotti, the bleak prospects for this type of reform are explained:

The UN Security Council, UNICEF, the High Commissioner on Refugees, and other UN agencies have spent much energy trying to keep Africa from spiralling into economic and political chaos. Yet the WTO predicted upon the conclusion of its Uruguay Round of agreements that, because of new rules increasing global competition for the commodities Africa exports, and newly required decreases in subsidies for the grains Africa imports, sub-Saharan Africa would lose another $\$ 200$ billion per year in capital outflows. ...

23. Abegaz, 1994:302.

24. Abegaz, 1994:6-7, citing the World Bank, 1989, 1992.

25. Abegaz, 1994:7. 
Many of the UN's specialized agencies have for years encouraged governments to increase their national budgets for education, health care, social welfare. Yet the World Bank and IMF, through conditions set on their structural adjustment loans to poor countries, exert great pressure to slash national budgets. Their pressure can directly result in diminishing social programs. ${ }^{26}$

\section{Evaluation of the models}

The shortcomings of both the neoclassical and structural models suggest that more is needed than just sound strategy. While rejecting the philosophy of the "neoclassical" model, Berhanu Abegaz suggests that a balance has to be struck between "the needs of short-term adjustment and the imperative of long-term growth" ${ }^{27}$ However, in neither of the models, nor in that of Abegaz, do we find any deliberation on the cultural prerequisites for sustained economic growth. Their common understanding is that if the micro and macro planning are done properly, the rest will follow. We wish to propose that more is needed than economic wisdom or adequate funds. With sincere appreciation for humanitarian aid to developing nations, we also have to note that more is necessary than such aid.

This brings us to the issue of culture. We wish to propose that there are cultural patterns that have to be understood, accommodated and modified in order to prepare the way for an African Renaissance. As we shall argue, the EOC has a strategic role to play in this. In the next section we shall review three strategic areas where cultural and religious issues can make a difference.

\section{Reform strategies}

While globalisation cannot be held responsible for Ethiopia's economic disasters, it has a decisive role - either negative or positive - to play in the reconstruction of the country. Africa is now entering a time where the regeneration of its economies has become a greater possibility than ever before. With the resolution of the Cold War and the dissolution of Apartheid an unprecedented number of new resources have locally and internationally become available for constructive action on the continent. The basic question to ask is, "What is necessary for an African/Ethiopian Renaissance?" Within the limited scope of this paper, we shall focus on the role of the EOC in this challenge.

\section{Agricultural reform}

The Ethiopian economy is heavily dependent on agriculture and the mass of the population $(75 \%)$ is employed there, while it generates $57 \%$ of the GDP. ${ }^{28}$ One could argue that, "Ethiopia is not poor because of its traditional agriculture; but its agriculture is traditional because the country is poor". ${ }^{29}$ While it cannot be disputed that enlightened agricultural policies and investment would make a great difference, the question has to be asked whether the cultural conditions for development exist. The fact is that Ethiopia's peasants, who form the majority of those working on the land, have never really appropriated

\footnotetext{
26. Summary on the www of Globalization and the United Nations, by Victor Menotti, International Forum on Globalization (accessed 2000-11-02 at http://www.ifg.org/un.html)

27. $1994: 310$

28. Hodd, 1998:729.

29. Quotation by Abegaz (1994:16) from Pickett (1991).
} 
sophisticated farming methods. ${ }^{30}$ Previously, under Emperor Haile Selassie, the landlords, the Church and the bureaucrats displayed little interest in increasing agricultural productivity. Abegaz notes that this lack of interest was "for reasons not fully understood". ${ }^{31}$ Another noteworthy fact is that the collectivisation and "villagerization" of the countryside by the Derg never managed to inspire the peasants. After the downfall of the Derg the peasants readily dismantled these measures. ${ }^{32}$ At present traditional farming methods are still deeply ingrained in their social and ideological construction of reality. Such farming methods are part and parcel of an Old Testament / traditional cosmology that has remained constant for many centuries.

As motivated well by Tsehai Berhane-Selassie in an article on "Ecology and Ethiopian Orthodox Theology" the Orthodox tradition also guard a number of sound ecological practices that need to be affirmed. ${ }^{33}$ His survey suggests that the EOC, who previously owned one third of the land, followed an eco-friendly policy that combined traditional agricultural practices with those prescribed in the Old Testament and were understood to be the divinely ordained manner for working the land. ${ }^{34}$

It is therefore evident that agricultural reform will not be sustainable until the rural population has developed a new way of looking at their own activity. ${ }^{35}$ This not only involves education, but a modification of life view. Enlightened and well-trained leadership can help to establish the ethos and a relevant view of nature necessary for a sustainable agricultural recovery. It is of long-term strategic importance that the cultural and religious resources of the population should be activated to this effect. Rather than treating religion as obstacle to agricultural reform, it has to be transformed into an ally. It is in this regard that the EOC with its 400000 priests and 30000 church schools can play a major role. ${ }^{36}$

\section{Reform of the bureaucracy}

Another strategic element in the long-term restructuring of the country is the establishment and strengthening of the bureaucratic middle class that was seriously decimated by the previous regime. Previously, under imperial rule and also under the Derg, the bureaucracy formed a stable class of its own. It could draw on the rich cultural heritage of Ethiopia. They not only are the inheritors of an indigenous system of writing (with 247 characters in the alphabet, somewhat like Linear B in the ancient Mediterranean world $)^{37}$ but also made use of the (Julian) calendar and a Biblical method keeping time (beginning their count of the hours from sunrise). However, the bureaucracy still employs many of the traditional conventions of a medieval manuscript culture, as is also fashionable in the EOC. A cursory review of the present bureaucracy reveals a level of expertise similar to that in Western countries in the 1940s and 1950s.

30. Orthodox peasants have been accused of observing "too many holidays". See the article of Aredo, discussing this problem, and pointing out that it is rather a lack of capital that causes under-production (in Pankhurst et. al. 1990:165-173, esp. 173).

31. $1994: 17$

32. Abegaz, 1994:317.

33. See article on "Ecology and Ethiopian Orthodox Theology" in Hallman, 1994:155-172.

34. Berhane-Selassie, in Hallman 1994:167.

35. Abegaz (1994:318) makes the point that strong public support is needed for reform programs. Obviously, this was previously lacking.

36. See Paulos, 1997:2.

37. See Woldegabir, 1996:85-87. 
It must also be remembered that before 1994 the bureaucratic class has never operated in service of a democratic constitution. This poses a real danger, for even when successful policies initiate recovery, government systems are often tempted to return to old habits that trigger new negative policy cycles. ${ }^{38}$ What happens to Ethiopia "after democracy" will to a large extent depend on the ability of the bureaucratic class to appropriate democratic values and manage a sophisticated economy. For any new system to become established in a society, a critical number of the participants in that society need to be carriers of the culture that supports that particular system.

We wish to suggest that not only Ethiopia, but also many new democracies in the world need a "second phase" in the process of democratisation. This second phase has to promote issues such as (a) establishing democratic values at grassroots level; (b) removing cultural as well as physical obstacles to social development; (c) releasing the creative energy of the disempowered; (d) devising international means of protecting weaker nations from unreasonable exploitation by speculators. In this regard a paradigm switch is required, in which the EOC can also play a role of strategic importance. Among other things it could promote a culture of human rights by re-interpreting its own tradition to play a role in a democratic society. Orthodox Christianity has a long tradition of fostering global perspectives. It also has a strong hold on the bureaucratic class because of the EOC's traditional links with centres of power.

\section{Resolution of armed confrontations}

A last strategic element, necessary for the economic recovery, is peace with neighbouring states. From the economic profile it is clear that Ethiopia is in no position to sustain a war economy. In the build-up to the 1998-2000 war with Eritrea, the media was flooded with narrow-minded chauvinistic propaganda. ${ }^{39}$ In this regard the EOC leadership has taken some initiative, trying to encourage a process of negotiation and reconciliation rather than opting for a military solution. This is a theme that could to be elaborated and expanded to the benefit of the country.

\section{The EOC as an agent of change?}

We can now return to the central question of this paper: To what extent can the EOC and the Orthodox tradition act as an agent of change in Ethiopia? From interviews we received some negative answers to this question. The rapid growth of the Protestant Mekane Jesu Church was ascribed to its high level of social involvement in comparison to the EOC. ${ }^{40}$ We were also told that evangelical Ethiopians were abandoning the EOC because of its inability to reach the people in a language they understand. ${ }^{41}$ Whether these perspectives can be generalized, remains difficult to ascertain because of a lack of quantifiable data. From interviews with officials and publications of the EOC a different picture emerges.

38. Abegaz, 1994:309.

39. In the time between 26 October to 10 November 1999 almost all major newspapers carried banners with slogans as, "Sovereignty at all cost". For foreigners it was clear that the war had little to do with national sovereignty.

40. The Mekane Jesu is a unified Protestant Church, representing main-line Protestantism. There are also a number of Charismatic churches that report rapid growth. The total number of Protestants is estimated to be 1.8 million (from interview with Burkhard, 1999).

41. Mekuria, 1997. 


\section{Profile of the EOC}

After the overthrow of the Derg, the EOC has managed to regain some of the ground it lost under the previous regime. ${ }^{42}$ Much of its confiscated property has been restored and under the present patriarch, Abba Paulos, it has also resumed a limited political role, trying to mediate in the conflict with Eritrea. Obviously the EOC finds itself in a process of transition, having to function in a secular state on an equal basis with all other religious institutions.

From EOC publications as well as interviews, it was clear that the EOC perceives itself as an agent of change. Orthodox Christians mainly point out three factors to illustrate this. The EOC

- is involved in a variety of social programs;

- has for a long time now taken its ecumenical role seriously; and

- $\quad$ is still fulfilling its role as repository and guardian of Ethiopian culture.

\section{Social involvement}

During the time of the Derg, the Church responded to socialism by projecting itself as a socially concerned body. Under the previous patriarch, Abune Tekle Haimanot a number of social programs were initiated, which included, e.g. in 1987-1988, food relief work, a fishery project, a reforestation project, refugee counselling and family and community development projects. ${ }^{43}$ This work is being carried on, as far as possible within its tight financial budget

\section{Ecumenical role}

The EOC takes prides in itself as member of the Pre-Chalcedonian (monophysite) Orthodox family of churches, along with the Coptic, Syrian, Indian (Malabar) and Armenian churches. ${ }^{44}$ This is reflected in its name as "The Ethiopian Orthodox Tewahedo Church", where the word "Tewahedo" refers to the single nature of Christ, the major doctrinal difference of these churches with the rest of Christianity. This does not prevent the EOC from being thoroughly involved in ecumenical relations. It is a founding member of the World Council of Churches and its ecumenical involvement ranges from hosting the All Africa Conference of Churches, to sending participants to A Parliament of the World's Religions. ${ }^{45}$

Though a priest in the city of Harar cut our interview short and dismissed us when hearing that we were Protestants, we did not find this attitude reflected in other centres or in the Patriarchate in Addis Ababa. On the contrary, there is an ecumenical openness that augurs well for the role of the EOC in a globalised world. This does not mean that officials are not annoyed by the competition and propaganda of other churches trying to lure away their flock. ${ }^{46}$

42. See The Church of Ethiopia, 1997:93.

43. In Meadot (1988:16-20) a review is given of the projects of the EOC's Development and Inter-Church Aid Department in 1987-1988.

44. See The Ethiopian Orthodox Tewahedo Church 1996:128.

45. See The Ethiopian Orthodox Tewahedo Church 1996:139-142.

46. See the remark by Abba Paulos, Patriarch of Ethiopia, that "we will continue to oppose in future the proselytism among its spiritual flock. This is an apostolic tradition performed to protect oneself and we understand that it will not offend well meaning members of any other church" (The Church of Ethiopia 1997:8) 


\section{The EOC as guardian of Ethiopian culture}

Though only $40 \%$ of the population are adherents of the EOC, it views itself as the guardian of Ethiopian culture in general. The distinctive features of the Orthodox tradition as developed in Ethiopia are proudly upheld as unique Ethiopian achievements. ${ }^{47}$ These features were developed during the time (from the $8^{\text {th }}$ to the $16^{\text {th }}$ centuries) that Ethiopia was relatively cut of from the rest of the word by its Muslim neighbours. Some of these include:

- The ancient Ge'ez language still used for access to its Biblical canon of 81 books and a number of unique extra-canonical books.

- The retention of the Old Testament Law, involving circumcision on the eighth day, purity rites and labour and agricultural practices.

- The use of an "ark" in the holy of holies in every church, only taken out for colourful ceremonies at specific occasions.

- A unique collection of Orthodox crosses. ${ }^{48}$

- A unique collection of hymns dating back to St. Yared $\left(6^{\text {th }}\right.$ century $){ }^{49}$

- The adaptation of Orthodox Church architecture and iconography to the local African forms. ${ }^{50}$

A further significant cultural contribution is the preservation of ancient techniques for producing manuscripts. Though the national level of literacy is relatively low, even among the advanced ethnic groups, the practice of manuscript writing is still being cherished. Ordinary Christians will, at a stage that they find their memory fading, prepare goatskins and ink and commit memorized Biblical passages and prayers to manuscript. ${ }^{51}$

Another cultural contribution is its maintenance of traditional Church schools, though the learning subjects are confined to religious materials and do not provide basic tuition in, e.g. modern hygiene and mathematics. These schools are structured much like the Rabbinical schools in $2^{\text {nd }}-5^{\text {th }}$ century Palestine. Learning is done by memorizing and then reciting sacred texts. By way of generalization we can observe that there are three levels in the church schools. On the first level pupils learn to read and memorize materials from Scripture, on the second they learn the correct pronunciation, and only on the third level they pay attention to the meaning. ${ }^{52}$ Both the Bible (in Ge'ez) and the traditional commentaries (in Amharic) are supposed to be memorized by advanced students. In an interview with the son of a priest who taught theological students, he insisted that his father had "many books" in his library. As it turned out the priest possessed about 15 books, most of which he had written himself. ${ }^{53}$

Alongside traditional training centres (e.g., the St. Paul Seminary in Addis Ababa) there are also newer institutions like the Holy Trinity Theological Seminary in Addis Ababa where teaching methods approach those found elsewhere in the world. However, the latter

47. See the book of Merahi (1999) in which he gives a review of the EOC's contribution to Ethiopian civilization.

48. See the foreword by Abune Paulos to The Ethiopian Crosses (1997).

49. See Giday, 1991:112ff.

50. See chapter by Adamu Amare and Belaynesh Mikael on the role of the Church in literature and art (in Paulos 1997:73-80).

51. For a description of writing instruments and manuscript preparation, see Merahi, 1999:139-157.

52. This description is a generalization of the system, described in detail in a publication of The Ethiopian

Orthodox Church, 1997:81-97. See also the publication The Church of Ethiopia, Past and Present, 1997:37-

62. Also Merahi, 1999:51-67.

53. Interview with Maaza Mekuria, Boston, January 1997. 
facility was only reopened after the downfall of the Derg. Its library was a gift of the late emperor Haile Selassie, and was confiscated by the Derg, who kept it locked away for the greater part of its seventeen years in power. It has only recently been restored to the seminary. The total number of 3600 books mostly dates from before 1974. The only computer available to the library and students was still not operative in November 1999. Though projects are under way to remedy the situation, it is clear that responsible theological education to meet the needs of the country will require a massive acquisition of books and computer equipment. The same situation was identified at the Patriarchate, where officials expressed the need for relevant and up to date reading materials.

\section{The EOC as "coherent centre" of Ethiopian history}

There are also historical reasons why the EOC projects itself as the coherent centre of Ethiopian society. In an official publication, it is said that "the EOC is indisputably the source of Ethiopian history..."54 Present day Ethiopia projects itself as the heir of the "highly developed civilization" originating in Axum in the third century BCE. ${ }^{55}$ The royal family dates its lineage back to Menelik I, the son of King Solomon and the Queen of Sheba. ${ }^{56}$ Because of the Byzantine idea of the theocratic state that has persisted since medieval times until the deposition of Haile Selassie in 1974, the history of the country was intimately interwoven with that of the Church. ${ }^{57}$

\section{Assessment of the social role and function of the EOC}

From the data just mentioned, it should be clear that the EOC is in a strategic position with regards to its influence on the cultural development of Ethiopia. At the same time, its potential of being a reactionary force in society, is also evident. Its social vision and involvement is seriously hampered by a general lack of funds, and amounts mostly to almsgiving. Its educational system is a powerful socializing force, but it is not tuned to serve the demands for economic development. One can say that the membership of the EOC in general is still operating within a late medieval manuscript culture. This is in stark contrast with the Patriarchate in Addis Ababa where the bureaucracy operates similar to the civil service in the country. While the traditional culture, as affirmed by the greater part of the EOC can present a major stumbling block to modernization, it would be short-sighted to leave it out of any plans for a restructuring of the economy. To some extent this culture provides a valuable point of departure for developing a modern culture.

\section{Religion and cultural transformation}

Perhaps the EOC is today the only society in the world where manuscript culture can still be studied as an operative system. Until recently all the scriptures of the Church were still used in manuscript form, most of them written in the Ge'ez language that as a spoken

54. The Church of Ethiopia 1997:39.

55. See the book of Giday (1991). For an impression of the remarkable Axumite civilization, see Phillipson, 1997.

56. In the book, Kebra Nagast (1995:45ff.) there is a description of how Menelik I was anointed as the king of Ethiopia. See also Giday, 1991:6-16, for an Ethiopian reflection on this history. In a publication reflecting the resolution of the Holy Synod of the EOC an extensive argument is given to prove that the Ethiopia mentioned in the Bible includes present-day Ethiopia (The Ethiopian Orthodox Tewahedo Church, 1997).

57. See Zewde, 1998:37 - "The EOC was also to play an important role in history as the ideological arm of the state." Lulseged (in Pankhurst et. al., 1990:3-11) explores the relationship of Christianity and nationalism in Ethiopia, and concludes, "It was thus the political manipulation of the rulers to promote their interest under the umbrella of one religion that eventually led to the fusion of Ethiopian identity with conversion to Christianity" (page 9). 
tongue became extinct in the seventh century. This is an old Semitic dialect, which forms the basis of the modern Amharic, Tigray and some other languages. Devotion to Ge'ez is particularly strong because it is believed that this was "the most important Semitic tongue spoken first by Adam". 58 It also preserves the context and sound quality of the Hebrew Bible and is close to the Aramaic of New Testament times. At several occasions we observed Ge'ez codices being used during services. ${ }^{59}$ When asked to read from the Ge'ez Bible, few of the priests in various churches could find the passages that we requested (e.g., 1 Corinthians 13, Psalm 23). One priest was most willing to show us the codices that were kept in the church, but it turned out that he could not read Ge'ez. He explained that he still was in training and was presently doing Grade 11 at a public school. ${ }^{60}$ The general impression was that the Ge'ez Bible was not accessible to a significant section of the clergy. ${ }^{61}$ We found printed Bibles in Amharic being used in some Orthodox churches, though not everywhere.

When considering the transformation of Ethiopian culture, one has to keep in mind that modern culture is typified by three revolutions: writing, the printing press, and the industrial revolution. Each of these revolutions has brought major shifts and upheavals in the social life of developed countries, sometimes with traumatic effects. Whereas traditional Sub-Saharan Africa has not experienced any of these transitions, Ethiopia is in the fortunate position of having taken the first step centuries ago.

Culturally speaking one cannot therefore equate Ethiopia with SSA without noting of some significant differences. The fact that Ethiopia has had centuries of experience with writing and has a recorded history, places it in a different category. The population has been culturally prepared for a faster assimilation of sophisticated culture than people from traditional tribal cultures. ${ }^{62}$

\section{Options for the EOC?}

In summary we can reiterate that the EOC has a strategic position in Ethiopian national life because of its access to the hearts and minds of a large section of the population. It has a tradition as an eco-friendly institution. It has a strong bureaucracy and strong institutions that it can depend on and has laid important foundations in establishing development programs and ecumenical relations.

Orthodox culture is already in a process of transformation, but visionary programs could expedite this. The optimal situation to aim for is a rapprochement to global culture while not sacrificing its identity. A re-interpretation of Christian theology and ethics for the relevant situation are just some of the many issues that will make a long-term difference.

For long-term development visionary programs are needed, combined with education and enhanced access to information. This would include focused programs for training of priests and church officials, which are designed and instituted on a much larger scale than at present. This also requires that the leadership be given an opportunity to study abroad in an environment where they are exposed to global culture. For the development of its social

58. The Church of Ethiopia, Past and Present,1997:56.

59. This practice was observed in Lalibela, November 6, 1999.

60. At the Birhan Selassie Church in Gondar, November 3, 1999.

61. In an article Oscar Löfgren finds that a critical and reliable edition of the Bible in Ge'ez is needed, which shows the absence of a scientific study of Scripture (in Proceedings of the Third International Conference of Ethiopian Studies, 1996:160).

62. This is the over-all impression of Pankhurst's valuable survey of the social history of Ethiopia from early medieval times until the middle of the 19th century (1990a). 
vision, programs such as the project "Faith and Earth-keeping" at the University of South Africa can possibly provide an opportunity for co-operation. ${ }^{63}$

\section{Conclusion}

Ethiopia proves to be a social-scientific laboratory where the intersection of social development and religion not only can be studied in a meaningful way, but also where such a study stands a chance of making a significant contribution.

It is clear that there are exceptional social, historical and cultural reasons why the EOC should be included in any long-term planning for the reconstruction of the country. Our visit to the areas of Bahir Dar, Gondar and Lalibela, as well as Addis Ababa, showed that the Orthodox religion remains deeply ingrained in the fibre of society in those regions. Christianity, in this form, has been appropriated by all levels of society, and noteworthy, especially that of the peasants. On the countryside numerous peasants were observed who carried symbols of the Orthodox tradition such as tattoos, pendants or crosses embroidered on their everyday clothes. Whether they will support enlightened initiatives of their church leadership remains to be seen. It is these people, at the grassroots of society, which will be further marginalized by globalisation unless something is done.

I wish to plea that institutions involved in foreign aid, incorporate religious bodies into their long-term planning. For this, cultural impact studies are necessary in the planning stages. Government agencies would do well to do the same. ${ }^{64}$ In this manner the EOC can be an agent of change, guiding its constituency to look globalisation squarely in the eyes.

\section{BIBLIOGRAPHY}

Azeze, Fekade 1998. Unheard Voices, Drought, Famine and God in Ethiopian Oral Poetry. Norwegian University of Science and Technology: Trondheim.

Balletto, Barbara Lawrence (ed.) 1995. Spectrum Guide to Ethiopia. Camerapix Publishers: Nairobi.

Brooks, Miguel F 1995. Kebra Nagast (The Glory of Kings). 'The True Ark of The Covenant', a modern translation by Miguel F. Brooks. The Red Sea Press: Lawrenceville, NJ.

Ethiopian Orthodox Tewahido Church 1997. Today's Ethiopia is Ethiopia of the Holy Scriptures, History and Antiquity. EOC: Addis Ababa.

Giday, Belai 1992. Ethiopian Civilization. Addis Ababa.

Hallman, David G (ed.)1994. Ecotheology, Voices from the South. Orbis Books: Maryknoll, New York.

Hodd, Michael 1998. East Africa Handbook, with Kenya, Tanzania, Uganda and Ethiopia. Footprint Handbooks: Bath, England.

Maedot, The Ethiopian Orthodox Tewahedo Church Annual Publication 1988. The Ethiopian Orthodox Tewahedo Church Foreign Relations Department: Addis Ababa.

63. This program is directed by Dr. David Olivier, Faculty of Theology, UNISA, and funded by Goldfields South Africa.

64. None of numerous searches that I conducted in libraries and the www showed up any such studies or programs on the scale that is needed. 
Menotti, Victor 2000. Globalization and the United Nations. Summary on the www. by the International Forum on Globalization. Accessed 2000-11-02 at http://www.ifg.org/un.html.

Merahi, Kessis Kefyalew. 1999. The Contribution of The Orthodox Tewahedo Church To the Ethiopian Civilization. Addis Ababa.

Pankhurst, Richard 1990a. A Social History of Ethiopia. Institute of Ethiopian Studies: Addis Ababa.

Pankhurst, Richard, Zekaria, Ahmed and Beyene, Taddese (eds.) 1990. Proceedings of the First National Conference of Ethiopian Studies. AAU Printing Press: Addis Ababa.

Paulos, Abba, Patriarch of Ethiopia (ed.) 1997. The Church Of Ethiopia, a panorama of history and spiritual life. EOC: Addis Ababa.

Phillipson, David W (ed.) 1997. The Monuments of Aksum. Addis Ababa University Press: Addis Ababa.

Pickett, James 1991. Economic development in Ethiopia: Agriculture, the market and the state. OECD Development Centre: Paris.

Proceedings of the Third International Conference of Ethiopian Studies, Vol. II 1996. Institute of Ethiopian Studies Haile Selassie I University: Addis Ababa.

The Church of Ethiopia, Past and Present 1997. EOC: Addis Ababa.

The Ethiopian Crosses 1997. Tensae Publishing House: Addis Ababa.

The Ethiopian Orthodox Tewahedo Church Faith, Order of Worship and Ecumenical Relations 1996. Tensae Publishing House: Addis Ababa.

Woldegabir, Semere 1996. Amharic for Foreigners. Addis Ababa.

World Bank 1989. Sub-Saharan Africa: From crisis to sustainable growth. Washington DC.

World Bank 1992. Governance and development. Washington DC.

Zewde, Bahru 1998. A Short History of Ethiopia and The Horn. Commercial Printing Ent: Addis Ababa.

\section{LIST OF INTERVIEWEES ${ }^{65}$}

Burkhard, Dr. Peter, Mekane Jesu Church, Addis Ababa.

Demissie, Dr Abebe, Acting Head of the Centre for Biodiversity.

Gebregziaber, Kashaz, Religious journalist at Patriarchate, Addis Ababa.

Gebru, Solomon, Patriarchate, Addis Ababa.

Mekuria, Maaza, Computer engineer. Interviewed in Boston, January 1997.

Melaku, Lule, Holy Trinity Theological Seminary of The Ethiopian Orthodox Church.

Molinaeux, Dr Louis, Polio expert, previously medical practitioner near Gondar.

Muche, Bilal, Western Gojam Culture Tourism and Information Department, Bahir Dar.

Tedik Tsega, Aba Kale, EOC Priest, Gondar.

Tekle Haimanot, Aba Wolde Tinsael, EOC Priest, Bahir Dar.

Vaidian, Father MM, Holy Trinity Theological Seminary of The Ethiopian Orthodox Church.

Wolde Hanna, Minasse, Patriarchate, Addis Ababa.

Yigsaw, Getnet, Tourist guide, Gondar.

65. All except Mekuria were interviewed between 26 October and 10 November 1999. While expressing my sincere thanks to these persons for their time and kind assistance, none of them can beheld responsible for positions taken in this article. 